\title{
Natural hybridisation between two coastal endemic species of Armeria (Plumbaginaceae) from Portugal. 2. Ecological investigations on a hybrid zone
}

\author{
C. Tauleigne-Gomes $\cdot$ C. Lefèbvre
}

Published online: 14 November 2008

(C) Springer-Verlag 2008

\section{Erratum to: Plant Syst Evol}

DOI 10.1007/s00606-008-0019-x

Unfortunately the original version of this article has been published with errors.

In the legend to Fig. 3 it must read "(filled circle: $p<0.05$; open circle: (n.s.) $p>0.05)$ " instead of "( filled circle: $p<0.05$; open circle: (n.s.) $p<0.05$ )".

The online version of the original article can be found under doi:10.1007/s00606-008-0019-x.

\section{Tauleigne-Gomes · C. Lefèbvre}

Laboratoire de Génétique et d'Ecologie Végétales,

Université Libre de Bruxelles, Chaussée de Wavre 1850,

1160 Brussels, Belgium

C. Tauleigne-Gomes $(\square)$

Jardim Botânico, Museu Nacional de História Natural,

Universidade de Lisboa, Rua da Escola Politécnica 58,

1250-102 Lisbon, Portugal

e-mail: ctgomes@fc.ul.pt 